\title{
A $15 q 25.2$ microdeletion phenotype for premature ovarian failure in a Chinese girl: a case report and review of literature
}

\author{
Zhen Chen ${ }^{1}$, Hong Chen², Ke Yuan² and Chunlin Wang ${ }^{2^{*}}$ (1)
}

\begin{abstract}
Background: Proximal microdeletions on chromosome 15q25.2 are very rare, and are associated with neurodevelopmental delay, inguinal hernia, chest deformities, and anemia. The minimum length missed so far is 1.4 Mb. However, there were no cases reported till date on microdeletions at position q25.2 on chromosome 15 with premature ovarian failure (POF).
\end{abstract}

Case presentation: We herein reported a POF case characterized by short stature with only $0.447 \mathrm{Mb}$ deletion on chromosome 15q25.2. The clinical and molecular characteristics in our patient showed the slightest clinical manifestations, with no clinical signs of neurodevelopmental delay, inguinal hernia, chest deformities, and anemia when compared to the previously reported cases. The microdeletions in our case included only 7 genes (HOMER2, FAM103A1, C15orf40, BTBD1, TM6SF1, HDGFRP3 and BNC1), and excluded the CPEB1 gene. Among these, the BNC1 gene is the only one that is known to be involved in reproduction. We hypothesized that the deletion of BNC1 gene in this patient led to haploinsufficiency, and consequently to POF.

Conclusions: The study of this case increased the knowledge on the molecular and phenotypic consequences of interstitial 15q25.2 deletion, emphasizing that BNC1 gene deletion in this region might contribute to POF.

Keywords: 15q25.2, Microdeletion, Premature ovarian failure, BCN1 gene

\section{Background}

Premature ovarian failure (POF) is a complex heterogeneous disease and a common genetic condition affecting $1 \sim 1.5 \%$ of women under 40 years of age, and the main manifestations include abnormal menstruation (amenorrhea, oligomenorrhea or frequent), elevated levels of gonadotropin $(\mathrm{FSH}>25 \mathrm{U} / \mathrm{L})$, and decreased female hormone level volatility. But in $50-80 \%$ of cases, POF is still classified as being idiopathic, suggesting a strong genetic association of the disease [1]. In some cases, POF is caused by single-gene mutations that are inherited by autosomes or X-linked, while it is caused by

\footnotetext{
* Correspondence: hzwangcl@zju.edu.cn

${ }^{2}$ Department of Pediatrics, The First Affiliated Hospital of Medical College, Zhejiang University, Hangzhou 310003, Zhejiang province, China Full list of author information is available at the end of the article
}

chromosomal abnormalities, such as Turner syndrome, in few others [2]. DNA microarray technology is used for detecting the submicroscopic copy number variation $(\mathrm{CNV})$ revealing the pathogenesis of rare and complex diseases. The chromosome $15 \mathrm{q} 25.2$ region has a complex genomic structure and four low-copy repeats, which mediate non-allelic homologous recombination and result in the deletion of chromosome fragments [3]. Till date, there are about 10 patients with proximal 15q25.2 microdeletions reported [3-6]. The clinical phenotypic features of these patients include retarded intellectual development, short stature, craniofacial deformities, congenital diaphragmatic hernia $(\mathrm{CDH})$, Diamond-Blackfan anemia (DBA), and mental disorders. In addition, some rare phenotypes included cleft lip, dextrocardia, and obstructive sleep apnea [3-8]. The clinical phenotype of 
these patients showed close association with the genes present in the deletion region. However, there are few reports on 15q25.2 microdeletions and POF.

We herein reported a case with $15 \mathrm{q} 25.2$ microdeletions and compared this patient with the previously reported female cases to propose the possible candidate genes for POF based on the observed characteristics.

\section{Case presentation}

A 14-year-9-month-old female who is the only child of healthy and nonconsanguineous Chinese parents was referred to our hospital for investigation due to her short stature and lack of menstruation. At birth, her weight was $3100 \mathrm{~g}$ and length was $50 \mathrm{~cm}$. She was born without any difficulty during delivery and her mental and motor abilities remained normal. She developed breasts when she was 13 years old but not menstruated yet. Physical examination revealed a height and weight of $143.9 \mathrm{~cm}$ $(-2.9 \mathrm{SD})$ and $29.5 \mathrm{Kg}(-2.98 \mathrm{SD})$, respectively. Karyotype analysis showed 46, XX. The breast development was stage B3 (with obvious enlargement and elevation of the whole breast) and pubic hair development was stage PH4 (the publc hair was long and dark and spread to the pubic region). The bone age is about 12 years old (Gruelich-Pyle). Pelvic ultrasound showed that the uterus size was about $2.5 \mathrm{~cm} \times 2.1 \mathrm{~cm} \times 2.7 \mathrm{~cm}$; and the ovary was not clearly seen. There were no abnormalities detected in the ultrasound results of urinary and cardiovascular systems. The baseline levels of reproductive hormones revealed LH of $10.40 \mathrm{IU} / \mathrm{L}$ (normal: 0.00 15.26), FSH of $45.5 \mathrm{IU} / \mathrm{L}$ (normal: 0.19-7.97), and E2 of $18.3 \mathrm{pmol} / \mathrm{L}$ (normal: 26.9-254.6).

Based on the breast development, short stature, amenorrhea and undetected ovaries in the 14-year-9-month girl, the baseline levels of LH and FSH were significantly increased, diagnosing POF. DNA microarray analysis (CytoOneArray chip from Phalanx Biotech company) showed a $15 \mathrm{q} 25.2$ heterozygous microdeletion from 83, 588,055 to $8,403,418$ (Fig. 1). The deletion of $15 q 25.2$ includes 7 genes: HOMER2, FAM103A1, C15orf40, BTBD1, TM6SF1, HDGFRP3 and BNC1. The aberration was neither detected in her father nor her mother, indicating that the deletion was arisen de novo. Genomic microdeletion involving chromosome $15 \mathrm{q} 25.2$ is a rare finding. Nevertheless, there are some reports of CNVs within this region that are associated with recognizable phenotypes. A search was performed in the NCBI and DECIPHER database (https://decipher.sanger.ac.uk/) and identified 7 patients carrying similar microdeletions. Figure 2 showed the size and location of the 15q25.2 deletion (chr15: 83588055-84,035,418) as compared to the published female cases.

Estrogen replacement therapy is generally used for patients with POF. However, the patient did not receive further treatment because of her parents' concern regarding the side effects.

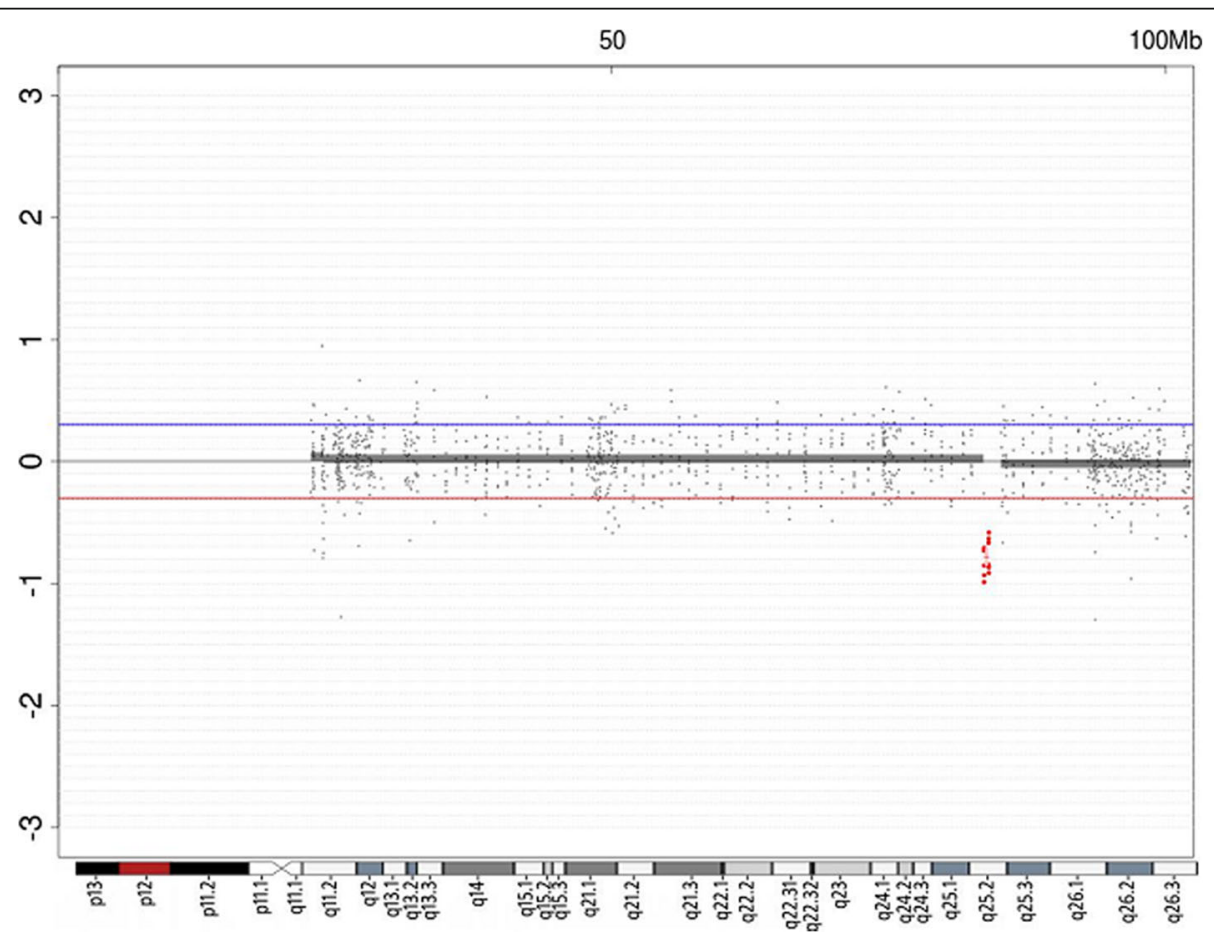

Fig. 1 DNA microarray profiles of the patient. The horizontal axis is the chromosome number, and the vertical axis is the signal ratio between the sample and the standard sample. The profile of Agilent array CGH showed a Log ratio of -1 , which indicated a heterozygous deletion 


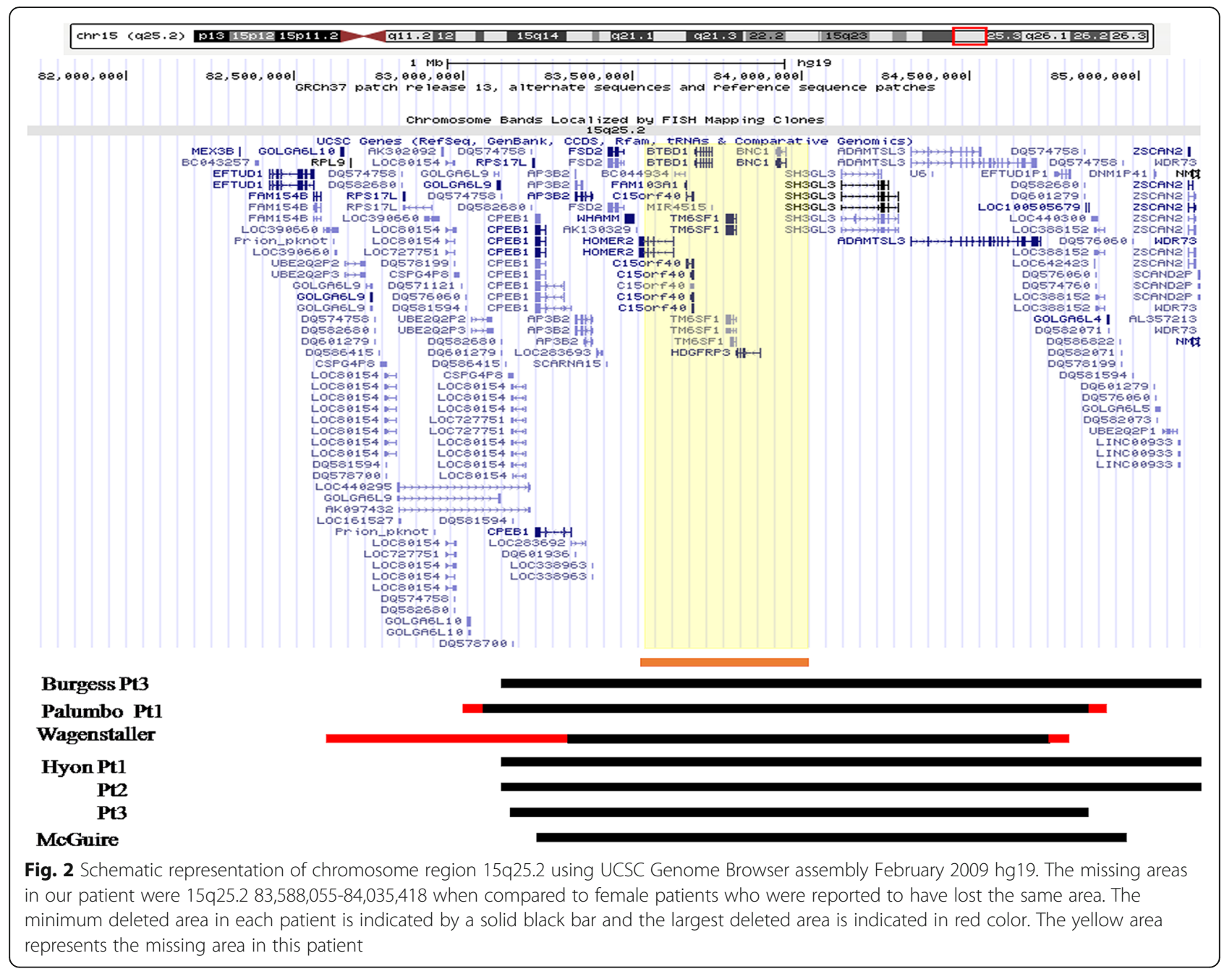

\section{Discussion and conclusions}

The chromosome 15q25.2 region has a complex genomic structure and four low-copy repeats that mediate non-allelic homologous recombination and result in deletion of chromosome fragments [3]. The clinical phenotype of these patients is closely related to the genes present in the deleted regions. The clinical phenotypes mainly included mental retardation, short stature, craniofacial deformity, CDH, DBA, and mental disorders. In addition, all female patients have POF [9]. Our patient presented with characteristics of short stature and ovarian dysplasia, without intellectual disability, anemia, structural malformation of the thorax and upper abdomen, venous thrombosis or other clinical manifestations. As reported previously, CPEB1 (cytoplasmic polyadenylation element-binding protein-1, OMIM 607342) is highly expressed in the brain and plays an important role in maintaining the production of mitochondrial ATP in nerve cells. Adaptor protein-3 (AP3) is a heterotetrameric vesicle-coat protein complex that constitutes AP3 complex subunit beta-2 (AP3B2, OMIM 602166) as a subunit of non-clathrin and clathrin-associated AP3, which plays a role in protein sorting in the late-Golgi/ trans-Golgi network (TGN) and/or endosomes. AP3 is involved in the sorting of a subset of transmembrane proteins targeted to lysosomes and lysosome-related organelles. Therefore, AP3B2 is thought to have neurospecific functions, such as releasing of the neurotransmitters. AP3 is a heterotetrameric vesicle-coat protein complex, and so deletion of $C P E B 1$ gene and $A P 3 B 2$ gene is related to the phenotype of neural abnormality, and our patient's microdeletion does not include these two genes, explaining as to why she has no clinical manifestations of the nervous system. It is currently believed that deletion of RPS17L (OMIM 180472) gene might be responsible for the cause of anemia in patients with a proximal $15 \mathrm{q} 25.2$ microdeletion, and no loss of this gene has occurred in this patient. BTBD1 (protein 1 containing BTB/POZ domain, OMIM 608530), HDGFRP3 (hepatoma derived growth factor-associated protein 3, OMIM 616643) and BCN1 (basculin 1, OMIM 601930) played roles in cell proliferation [10]. Wat et al. [5] have 
Table 1 Clinical features and molecular breakpoints of patients with 15q25.2 microdeletions

\begin{tabular}{|c|c|c|c|c|c|c|c|c|}
\hline & $\begin{array}{l}\text { Burgess } \\
\text { Pt3 [6-8] }\end{array}$ & $\begin{array}{l}\text { Palumbo } \\
\text { Pt1 [16] }\end{array}$ & $\begin{array}{l}\text { Wagenstaller } \\
\text { [4] }\end{array}$ & $\begin{array}{l}\text { Hyon } \\
\text { Pt1 [9] }\end{array}$ & $\begin{array}{l}\text { Hyon } \\
\text { Pt2 [9] }\end{array}$ & $\begin{array}{l}\text { Hyon } \\
\mathrm{Pt3}[9]\end{array}$ & $\begin{array}{l}\text { McGuire } \\
\text { Pt87 [10] }\end{array}$ & Present case \\
\hline Age (years) & 5-month old & 9 & 11 & NR & NR & $N R$ & $N R$ & 14 \\
\hline Gender & Female & Female & Female & Female & Female & Female & Female & Female \\
\hline $\begin{array}{l}\text { Height }(\mathrm{cm}) \\
\text { /weight (kg) }\end{array}$ & $N R$ & $120 / 22$ & NR & $168 / 70$ & $156 / 48$ & $156 / 59$ & $N R$ & $143.9 / 29.5$ \\
\hline First menses & NA & $N R$ & $N R$ & Primary amenorrhea & 19 & $\begin{array}{l}\text { Primary } \\
\text { amenorrhea }\end{array}$ & $\begin{array}{l}\text { Primary } \\
\text { amenorrhea }\end{array}$ & $\begin{array}{l}\text { Primary } \\
\text { amenorrhea }\end{array}$ \\
\hline $\begin{array}{l}\text { Size of the ovary } \\
\text { (right/left), mm }\end{array}$ & NA & NR & NR & Not found & $\begin{array}{l}19 \times 12 / \\
20 \times 11\end{array}$ & $\begin{array}{l}25 \times 8 / \\
26 \times 9\end{array}$ & $N R$ & Not found \\
\hline $\begin{array}{l}\text { FSH (IU/L)/ LH } \\
(\mathrm{IU} / \mathrm{L}) \\
\text { / E2(pmol/L) }\end{array}$ & NR & $N R$ & $N R$ & $33 / 29 / 39$ & $44 / 19 / 90$ & $65 / 48 / 100$ & $N R$ & $10.4 / 45.5 / 18.3$ \\
\hline $\begin{array}{l}\text { Intellectual } \\
\text { disability or } \\
\text { developmental } \\
\text { delay }\end{array}$ & $\begin{array}{l}\text { Mild } \\
\text { delay }\end{array}$ & $\begin{array}{l}\text { moderate to severe } \\
\text { cognitive delay }\end{array}$ & $\begin{array}{l}\text { Mild mental and } \\
\text { psychomotor } \\
\text { retardation }\end{array}$ & $\begin{array}{l}\text { Behavioral disorders, } \\
\text { progressive intellectual } \\
\text { deficiency }\end{array}$ & None & None & $N R$ & None \\
\hline $\begin{array}{l}\text { Microdeletion in } \\
15 q 25.2\end{array}$ & $2.5 \mathrm{Mb}$ & $1.6 \mathrm{Mb}$ & $\begin{array}{l}\sim 1.4 \mathrm{Mb} / \sim 2.2 \\
\mathrm{Mb}\end{array}$ & $2.5 \mathrm{Mb}$ & $2.5 \mathrm{Mb}$ & $1.6 \mathrm{Mb}$ & $1.67 \mathrm{Mb}$ & $0.447 \mathrm{Mb}$ \\
\hline Inheritance & De novo & De novo & De novo & De novo & NR & $N R$ & $N R$ & De novo \\
\hline
\end{tabular}

FSH Follicle stimulating hormone, LH Luteinizing hormone, E2 Estradiol, NR Not recorded, NA Not applicable, UNK Unknown, N Normal

suggested that these genes were associated with short stature and developmental delay in patients with 15q25.2 deletion.

Hyon et al. [9] have reported three patients with $15 \mathrm{q} 25.2$ microdeletions that are associated with ovarian insufficiency. Their minimum common area (chr15: 83223426 to $84,832,932$ ) included 12 genes (CPEB1, AP3B2, FSD2, WHAMM, HOMER2, FAM103A1, C15orf40, BTBD1, TM6SF1, HDGFRP3, BNC1, $S H 3 G L 3)$, and the heterozygous deletion of CPEB1 genes was believed to be responsible for the early POF in females [9]. The clinical features of female patients with 15q25.2 deletion are summarized in Table 1. However, the microdeletions in our patient included only 7 genes (HOMER2, FAM103A1, C15orf40, BTBD1, TM6SF1, $H D G F R P 3$ and $B N C 1$ ), which excluded the CPEB1 gene (chr15:83211951-83,317,612). Among these, the BNC1 gene is the only one known to be involved in reproduction. Human $B N C 1$ gene encodes zinc finger protein basonuclin-1 [11]. BNC1 is a zinc finger protein that is present in the epidermal basal cell layer and hair follicles. It is also abundantly found in the germ cells of the testes and ovaries. Furthermore, it plays a regulatory role in keratinocyte proliferation, and might also act as a regulator of rRNA transcription. Wittgenstein et al. believed that BNC1 gene is involved in oogenesis and is closely related to POF [12]. BNC1 as a transcription factor is involved in oogenesis and folliculogenesis [13]. Knockout of $B N C 1$ gene resulted in female infertility [14]. Recent study found that knockdown of $B N C 1$ gene can reduce BMP15 and p-akt levels and inhibit meiosis in the oocytes. Female mouse models with Bnc1 mutation showed similar phenotype as that of POF [15]. Zhang et al. have reported a familial POI caused by $B N C 1$ mutation [15]. The patients with POF reported by Hyon et al. missed both $C P E B 1$ and $B N C 1$ genes, and believed that $C P E B 1$ is the cause of POF. However, the importance of $B N C 1$ gene in the occurrence and development of POF was proved in our case. Therefore, we hypothesized that deletion of $B N C 1$ gene in this patient led to haploinsufficiency and consequently to POF.

In summary, this study extended a relatively minor phenotype of the proximal deletion of chromosome $15 \mathrm{q} 25.2$ with POF, and revealed that $B N C 1$ gene might be an important candidate gene for POF.

\section{Abbreviations \\ POF: Premature ovarian failure; CMA: Chromosomal microarray chip; AP3: Adaptor protein-3; CNV: Copy number variation; BNC1: Basonuclin 1; $\mathrm{CDH}$ : Congenital diaphragmatic hernia}

\section{Acknowledgements}

Not applicable.

\section{Authors' contributions}

CW contributed to the design of the study. ZC and HC performed the literature search and reviewed the data. ZC and KY drafted the manuscript. All the authors read and approved the final manuscript.

\section{Funding}

This work was supported by grants from the National Natural Science Foundation of China (Grants No.11571309) and the key Research and Development Program of Zhejiang Province (2020C03121). The funder had no role in study design, data collection and analysis, decision to publish, or in the preparation of the manuscript.

\section{Availability of data and materials}

The datasets analyzed during the current study are available from the corresponding author on reasonable request. 


\section{Ethics approval and consent to participate}

The Ethics approval was obtained from the Research Ethics Committee of the First Affiliated Hospital, College of Medical, Zhejiang University. The written consent to participate in the genetic testing was obtained from both the patient (the parents signed the form on behalf of their child) and her parents. We confirm that we have read the Journal's position on issues involved in ethical publication and affirm that this report is consistent with those guidelines.

\section{Consent for publication}

Written informed consent was obtained from the patient's parents for publication of this Case Report and any accompanying images. A copy of the written consent is available for review by the Editor of this journal.

\section{Competing interests}

The authors declare that they have no competing interests.

\section{Author details}

'Department of Pathology, The First Affiliated Hospital of Medical College, Zhejiang University, Hangzhou 310003, Zhejiang province, China.

${ }^{2}$ Department of Pediatrics, The First Affiliated Hospital of Medical College,

Zhejiang University, Hangzhou 310003, Zhejiang province, China.

Received: 6 December 2019 Accepted: 31 August 2020

Published online: 07 September 2020

\section{References}

1. Laissue P. Aetiological coding sequence variants in non-syndromic premature ovarian failure: from genetic linkage analysis to next generation sequencing. Mol Cell Endocrinol. 2015;411:243-57.

2. Pouresmaeili F, Fazeli Z. Premature ovarian failure: a critical condition in the reproductive potential with various genetic causes. Int J Fertil Steril. 2014; 8(1):1-12.

3. Mefford HC, Clauin S, Sharp AJ, Moller RS, Ullmann R, Kapur R, Pinkel D, Cooper GM, Ventura M, Ropers $\mathrm{HH}$, et al. Recurrent reciprocal genomic rearrangements of $17 q 12$ are associated with renal disease, diabetes, and epilepsy. Am J Hum Genet. 2007;81(5):1057-69.

4. Wagenstaller J, Spranger S, Lorenz-Depiereux B, Kazmierczak B, Nathrath M, Wahl D, Heye B, Glaser D, Liebscher V, Meitinger T, et al. Copynumber variations measured by single-nucleotide-polymorphism oligonucleotide arrays in patients with mental retardation. Am J Hum Genet. 2007;81(4):768-79.

5. Wat MJ, Enciso VB, Wiszniewski W, Resnick T, Bader P, Roeder ER, Freedenberg D, Brown C, Stankiewicz P, Cheung SW, et al. Recurrent microdeletions of $15 q 25.2$ are associated with increased risk of congenital diaphragmatic hernia, cognitive deficits and possibly diamond--Blackfan anaemia. J Med Genet. 2010;47(11):777-81.

6. Cooper GM, Coe BP, Girirajan S, Rosenfeld JA, Vu TH, Baker C, Williams C, Stalker H, Hamid R, Hannig V, et al. A copy number variation morbidity map of developmental delay. Nat Genet. 2011:43(9):838-46.

7. Doelken SC, Seeger K, Hundsdoerfer P, Weber-Ferro W, Klopocki E, GraulNeumann L. Proximal and distal 15q25.2 microdeletions-genotypephenotype delineation of two neurodevelopmental susceptibility loci. Am J Med Genet A. 2013;161A(1):218-24.

8. Burgess T, Brown NJ, Stark Z, Bruno DL, Oertel R, Chong B, Calabro V, Kornberg A, Sanderson C, Kelly J, et al. Characterization of core clinica phenotypes associated with recurrent proximal 15q25.2 microdeletions. Am J Med Genet A. 2014;164A(1):77-86.

9. Hyon C, Mansour-Hendili L, Chantot-Bastaraud S, Donadille B, Kerlan V, Dode C, Jonard S, Delemer B, Gompel A, Reznik Y, et al. Deletion of CPEB1 gene: a rare but recurrent cause of premature ovarian insufficiency. J Clin Endocrinol Metab. 2016;101(5):2099-104.

10. McGuire MM, Bowden W, Engel NJ, Ahn HW, Kovanci E, Rajkovic A. Genomic analysis using high-resolution single-nucleotide polymorphism arrays reveals novel microdeletions associated with premature ovarian failure. Fertil Steril. 2011;95(5):1595-600.

11. Tseng H, Green H. Basonuclin: a keratinocyte protein with multiple paired zinc fingers. Proc Natl Acad Sci U S A. 1992:89(21):10311-5.

12. Tsuiko O, Noukas M, Zilina O, Hensen K, Tapanainen JS, Magi R, Kals M, Kivistik PA, Haller-Kikkatalo K, Salumets A, et al. Copy number variation analysis detects novel candidate genes involved in follicular growth and oocyte maturation in a cohort of premature ovarian failure cases. Hum Reprod. 2016;31(8):1913-25.

13. Assou S, Anahory T, Pantesco V, Le Carrour T, Pellestor F, Klein B, Reyftmann L, Dechaud H, De Vos J, Hamamah S. The human cumulus--oocyte complex gene-expression profile. Hum Reprod. 2006;21(7):1705-19.

14. Ma J, Zeng F, Schultz RM, Tseng H. Basonuclin: a novel mammalian maternal-effect gene. Development. 2006;133(10):2053-62.

15. Zhang D, Liu Y, Zhang Z, LV P, Liu Y, Li J, Wu Y, Zhang R, Huang Y, Xu G, et al. Basonuclin 1 deficiency is a cause of primary ovarian insufficiency. Hum Mol Genet. 2018;27(21):3787-800.

\section{Publisher's Note}

Springer Nature remains neutral with regard to jurisdictional claims in published maps and institutional affiliations.
Ready to submit your research? Choose BMC and benefit from:

- fast, convenient online submission

- thorough peer review by experienced researchers in your field

- rapid publication on acceptance

- support for research data, including large and complex data types

- gold Open Access which fosters wider collaboration and increased citations

- maximum visibility for your research: over $100 \mathrm{M}$ website views per year

At BMC, research is always in progress.

Learn more biomedcentral.com/submissions 